\title{
Human brain subventricular zone-derived neural stem cells (NSCs) isolation from stroke patients - a pilot study in Hospital Universiti Sains Malaysia (Hospital USM), Malaysia
}

\author{
Suat Cheng Tan ${ }^{a, \#, *}$, In Nee Kang a,* , Abdul Rahman Izaini Ghani ${ }^{b, c}$, Shaharum Shamsuddin a \\ ${ }^{a}$ School of Health Sciences, Health Campus, Universiti Sains Malaysia, 16150 Kubang Kerian, Kelantan, Malaysia \\ ${ }^{\mathrm{b}}$ Department of Neurosciences, School of Medical Sciences, Health Campus, Universiti Sains Malaysia, 16150 Kubang Kerian, \\ Kelantan, Malaysia \\ 'Hospital USM, Health Campus, Universiti Sains Malaysia, 16150 Kubang Kerian, Kelantan, Malaysia \\ * Both authors contributed equally to the work described
}

Dr. Suat Cheng Tan, School of Health Sciences, Health Campus, Universiti Sains Malaysia, 16150 Kubang Kerian, Kelantan, Malaysia

\section{Summary}

Ischemic stroke is caused by cerebral vessel occlusion, resulting in an area of ischemia where the brain tissue irreversibly damaged due to inadequate oxygen and nutrients. Neural stem cell (NSC) grafting has emerged as a potential regenerative therapy for stroke. Here, we described a pilot clinical study of NSC isolation from subventricular zone (SVZ) of human brain. In this preliminary study, nine patients admitted to Hospital Universiti Sains Malaysia (Hospital USM) with cerebral vascular accident (CVA, i.e. ischemic or hemorrhagic stroke) and necessitating brain resection were recruited. During surgery, SVZ biopsies were excised, weighted and the morphological structure of clinical biopsies were recorded. Then the biopsies were digested and cultured using neurosphere or monolayer culture methods. Out of nine clinical samples, we successfully obtained neurospheres-like cells from five of the patients' SVZ biopsy, while monolayer culture grew out from two patients'
Phone: $+609-7677776$

Fax: $+609-7677515$

E-mail: tansc@usm.my
SVZ biopsy. Characterization assay using immunocytochemistry probed with nestin (NSC marker) successfully proved that these cells were NSCs. For the rest of samples, the isolation of SVZ derived-NSC was unsuccessful due to the insufficient SVZ tissue sampling. The tissue obtained were mainly connective or blood tissue, proved by the accumulation of floating cells after 24 hours in culture. In conclusion, NSCs were successfully obtained from some stroke patients SVZ. However, the quantity and quality of isolated cells are tissue-dependent, thus, surgical sampling technique and biopsy sizes are important in ensuring a good NSC isolation efficiency. This study could be an essential guidance for future NSC isolation study in our department.

\section{Keywords}

Primary neural stem cell isolation, stroke therapy, Hospital Universiti Sains Malaysia (Hospital USM), neurosphere, monolayer culture. 


\section{Introduction}

Stroke is the third leading cause of death in Malaysia; it is also the major causal factor of severe and long-term functional disability in adults $[1,2]$. There are two major types of stroke, namely ischemic stroke and hemorrhagic stroke. Ischemic stroke is characterized by thrombotic or embolic occlusion of cerebral artery, thereby restricts oxygen and nutrients supplies to an area of the brain. In contrary, hemorrhagic stroke is characterized by rupture of a blood vessel on or within the brain, subsequently causing severe bleeding into brain parenchyma. In Malaysia, most patients had ischemic stroke rather than hemorrhagic stroke [3].

In brain, neurons constantly demand for high glucose to perform cerebral functions [4]. Therefore, disrupted blood flow to the brain for as brief as 5 mins or less could be deadly to neurons. During ischemic stroke, interruption of blood flow attributed oxygen and glucose deprivation (OGD). Following OGD, the cellular metabolism switches from aerobic to anaerobic glycolysis for of adenosine triphosphate (ATP) production until existing pool of glucose is completely depleted [4]. Nevertheless, the efficiency of ATP production by anaerobic glycolysis is much lower compared to mitochondrial oxidative phosphorylation (OXPHOS) in which only 2 molecules of ATP for each molecule of glucose is produced compared to 34 ATP molecules produced under OXPHOS metabolism [5]. As a result, ATP consumption exceeds production and drives energy failure in the brain. In addition, anaerobic glycolysis also produces ion $\mathrm{H}+$ and lactate, lowering the $\mathrm{pH}$ and causes rapid intracellular acidosis.

Following rapid ATP deficit, activity of ATP-dependent transport systems on the plasma membrane of neuron such as $\mathrm{Na}^{+} / \mathrm{K}^{+}$-ATPase, $\mathrm{K}^{+} / \mathrm{Ca}^{2+}$-ATPase and $\mathrm{Ca}^{2+}$-ATPase pumps also are affected [6]. Maintenance and restoration of ion gradients by these pumps are important to regulate neuron signaling processes such as postsynaptic and action potentials, as well as uptake and recycling of neurotransmitters [6]. Failure of the energy-dependent ion pump causes ionic imbalances which induce transient osmotic gradients in the brain, resulting in water influx, cell swelling, edema and ultimately initiates a cascade of pathophysiologic cellular and molecular mechanisms such as glutamate excitotoxicity, inflammation and free radical overload, leading to irreversible brain damage [7].

The cell death that occurs following ischemic stroke can be reduced if the occlusions are removed quickly and tissue reperfusion is restored. In stroke animal study, it had been demonstrated that damage could be limited if reperfusion occurred within three hours after the onset of stroke $[8,9]$. Rapid restoration of blood flow to the infarcted brain tissue can be achieved by administration of thrombolytic agents which digest the clot. Existing pharmacological treatment for ischemic stroke including a combination of thrombolytic agent such as tissue plasminogen activator to break up blood clot, anti-platelet agents to prevent blood clots formation and/or statins to lower cholesterol levels in the blood [10]. Although current standard therapies allow restoration of blood supply or significant control against stroke symptoms, these treatments cannot completely restore the brain function because the central nervous system does not regenerate. A substantial portion of the lost brain functions can be regained by transferring the tasks to other neurons through stroke rehabilitation. Nonetheless, stroke rehabilitation is a long yet less efficient physical therapy. The limitation of these current stroke therapies has led to the demand for an alternative therapy to regenerate damaged brain tissue and restore total brain function [11].

Recently, stem cell therapy has emerged as a potential approach for treating neurodegenerative diseases and stroke. The transplanted cells may help to create new circuitry and express factors that protect existing cells. Neural stem cells (NSCs) are considered as the most optimal cell type for stem cell-mediated therapy of brain disorders. This is because they share the same tissue origin of the damaged brain cells and are originally meant to replenish the brain cells in vivo. By definition, NSCs are uncommitted cells that can self-renew extensively throughout lifetime or differentiate into different neuronal and glial subtypes in the brain [12]. In human brain, NSCs reside in two high-density cell division sites, the subventricular zone (SVZ) and subgranullar zone (SGZ) [13]. In the SGZ, NSCs reside along the lining of the dentate gyrus and hilus [14]. Hence, it is difficult to isolate SGZ-derived NSCs without damaging the surrounding brain tissue because they reside in the hippocampus interior. On the other hand, the SVZ is located at the lateral wall of the lateral ventricle [14]. The area is maintained in the adults as mitotically active area and NSC can be isolated endoscopically from this area for autologous transplantation [15]. Therefore, SVZ-derived NSCs provide the greater potential for clinical applications.

A number of publications have been described on isolation and expansion of human SVZ-derived biopsies [16-18]. The NSCs were expanded either through neurosphere $[17,18]$ or monolayer culture [16]. Nevertheless, no defined work has been performed to compare the efficiency of both neurosphere and monolayer culture for human NSC derived from a same SVZ biopsies. Furthermore, there is no previous study has been done in Hospital Universiti Sains Malaysia (Hospital USM) to excise human SVZ biopsy for NSC isolation. Therefore, in this study, we aimed a pilot study to isolate NSCs from the SVZ of patient with CVA or traumatic brain injury admitted to Hospital USM and developed a method for the isolation and expansion of NSCs for further stroke therapy study in Hospital USM. Besides, the method established in this study is specific to local genetic population profile, thus could potentially provide a more specific cell source for local NSC genetic and epigenetic study. According to Malaysian National Health and Morbidity Survey (NHMS), the prevalence of stroke among Malaysians increased sharply between 2006 and 2011 [2]. As a result, stroke causes an economic burden on health-care budgets and the whole nation economic development, reiterates the need for new therapies that can improve the effectiveness of stroke treatment for local population. Thus, the pilot clinical study described in this study is significantly useful for the researchers and clinicians in Hospital USM to establish future clinical application of stem cell-based therapy for stroke. 


\section{Materials and methods}

\section{Patient recruitment and tissue sampling}

Patients admitted to Hospital USM with diagnosed cerebral vascular accident (CVA, i.e. ischemic or hemorrhagic stroke) or with moderate to severe head injury (Glascow Come Score (GCS) between 3 and 13) after computed tomography magnetic resonance image (CT-MRI) confirmation and necessitating brain resection were recruited. Patients with severe coagulation were excluded from the study. All participants provided their written informed consent to participate in this study. A total of nine $(n=9)$ fresh surgical specimens sized $<5 \mathrm{~mm}^{3}$ were obtained from SVZ using the frameless stereotactic neuronavigation system by professional neurosurgeon team in Hospital USM. The tissue specimens were transported in a conical tube (BD Biosciences, USA) containing ice cold saline with $10 \%$ penicillin/streptomycin (GIBCO, USA) to the cell culture laboratory with minimal delay. The weight of the conical tube was measured before and after adding the biopsies to it. Then, the weight of the tissue specimen was obtained from subtraction of these two weights. All the procedure described here had been approved by the Human Research Ethic Committees, Universiti Sains Malaysia, FWA Reg. No.: 00007718; IRB Reg. No: 00004494.

\section{Brain biopsy dissection and disaggregation}

For the preparation of brain SVZ biopsy for stem cell isolation, the whole tissue was removed from the ice-cold conical tube onto a sterilized petri dish in a clean Biosafety Cabinet. The tissue specimen was rinsed with ice cold D-PBS without calcium and magnesium (Invitrogen, USA) to remove excess blood or connective tissue before dissected into small explants on ice using surgical blade. After microdissection, the tissue explants were digested using $0.05 \%$ Trypsin-EDTA (Invitrogen, USA) for 5 minutes at $37^{\circ} \mathrm{C}$ to further disaggregate the tissue. After 5 minutes, the enzymatic dissociation was inhibited by addition of equal amount of soybean trypsin inhibitor (Sigma, USA) with Deoxyribonuclease I (DNase I) (Sigma, USA). To achieve a single cell suspension, the cell suspension was subjected to sequential trituration using pipettes of decreasing diameter. Then, the cell suspension was filtered through a $40 \mu \mathrm{m}$ cell strainer to remove cell debris. The cell suspension was spun at $1500 \mathrm{rpm}$ for 5 minutes and the cell pellet was resuspended in $1 \mathrm{ml}$ of NSC serum-free media comprised of $1 \mathrm{X}$ Knockout D-MEM/F-12 (GIBCO, USA), 2 mM Glutamax I supplement (GIBCO, USA), 50X B27 supplement (GIBCO, USA), 20 ng/mL basic Fibroblast Growth Factor (bFGF) (GIBCO, USA) and $20 \mathrm{ng} / \mathrm{mL}$ Epidermal Growth Factor (EGF) (GIBCO, USA) and $2 \mathrm{mg} / \mathrm{mL}$ Heparin (STEMCELL Technologies, USA).

\section{Coating cell culture flasks for human NSC isolation}

Culture vessels were coated with either Poly-D-lysine (PDL)/ laminin (Sigma, USA) or CELLstart ${ }^{\mathrm{TM}}$ CTS $^{\mathrm{TM}}$ (GIBCO, USA) coating agent. To coat a T-25 flask with PDL/laminin, $3 \mathrm{~mL}$ of $10 \mu \mathrm{g} / \mathrm{mL}$ PDL was added and incubated for 2 hours at $37^{\circ} \mathrm{C}$. Then, the PDL solution was removed completely and rinsed thoroughly twice with $3 \mathrm{~mL}$ of cell culture grade water because excess PDL can be toxic to the cells. Next, $3 \mathrm{~mL}$ of
$10 \mu \mathrm{g} / \mathrm{mL}$ laminin solution was added and incubate at $37^{\circ} \mathrm{C}$, in the dark, for $2 \mathrm{~h}$. Prior to use, the flask was washed twice with $4 \mathrm{~mL}$ of DPBS without calcium and magnesium. On the other hand, to coat a T-25 flask with CELLstart ${ }^{\mathrm{TM}}$ CTS $^{\mathrm{TM}}, 20$ $\mu \mathrm{L}$ of CELLstart ${ }^{\mathrm{TM}} \mathrm{CTS}^{\mathrm{TM}}$ was diluted in $2 \mathrm{~mL}$ of $1 \mathrm{X}$ D-PBS with calcium and magnesium and added into a T-25 flask. The flask was then incubated at $37^{\circ} \mathrm{C}$ in a humidified chamber with $5 \% \mathrm{CO}_{2}$ for $1 \mathrm{~h}$. Used CELLstart ${ }^{\mathrm{TM}} \mathrm{CTS}^{\mathrm{TM}}$ was aspirated and the coated culture vessels were rinsed once with $3 \mathrm{~mL}$ of $1 \mathrm{X}$ D-PBS without calcium and magnesium prior to cell seeding.

\section{Isolation of human Neural Stem Cells (NSCs)}

The total number of viable cells after enzymatic dissociation was determined by cell counting using CountessTM automated cell counter. Briefly $10 \mu \mathrm{L}$ of single cell suspension in NSC serum-free media was aspirated and diluted in $10 \mu \mathrm{L}$ of $0.4 \%$ trypan blue solution. The cells were mixed completely and $10 \mu \mathrm{l}$ of the cells was carefully filled into the Countess cell counting chamber slide. Non-viable cells appeared blue whilst viable cells remained opaque. In this work, only viable cells were included in calculation of the cell concentration. After cell counting, the cells were split into two portions and cultured using two different methods namely: neurosphere culture or adherent monolayer culture. For neurosphere culture, the cell suspension was added to non-coated T-25 flask, while for adherent monolayer culture, the cell suspension was added to pre-coated T-25 flask (as described in previous section). For both methods, the cells were seeded at a final density of $1.0 \times 10^{5}$ cells $/ \mathrm{cm}^{2}$ and incubated in a humidified incubator under $5 \% \mathrm{CO}_{2}$ at $37^{\circ} \mathrm{C}$ for up to 4 weeks or until the monolayer cell got confluent or the free-floating spheres achieved within $150 \mu \mathrm{m}$ in diameter. Thereafter, the cells were harvested and passaged.

\section{Immunocytochemistry}

The harvested cells were seeded onto CELLstart ${ }^{\mathrm{TM}}$ CTS $^{\mathrm{TM}-}$ coated glass coverslips in a 24 -well plate and incubated at $37^{\circ} \mathrm{C}$ in the standard $\mathrm{CO}_{2}$ incubator until the monolayer cell get $70 \%$ confluent. Prior to ICC, the medium was discarded and the cell monolayer was rinsed with $500 \mu \mathrm{L}$ of $1 \mathrm{X}$ D-PBS with calcium and magnesium. The cells were fixed, permeabilized and blocked. Then, the cells were probed with anti-nestin (NSC marker) (Pierce, MA1-110) and anti-TUBB3 (neuron marker) (Novus Biologicals, NB100-479) or anti-GFAP (glial marker) (Abcam, ab7260) primary antibodies for double staining. A second incubation was performed using anti-mouse IgG-Alexa Fluor ${ }^{\oplus} 488$ (Abcam, ab150105) and anti-rabbit IgG-Alexa Fluor ${ }^{\oplus 55}$-conjugated (Abcam, ab150074) secondary antibodies. The cells were counterstained with NucBlue ${ }^{\varpi}$ (DAPI) (Invitrogen, USA) fixed cell stain and mounted on glass slides using ProLong ${ }^{\oplus}$ Diamond Antifade Mountant (Molecular Probes, USA).

\section{Results}

\section{Biopsy Weight}

Biopsies were successfully obtained from SVZ of nine patients. The weight of biopsies ranged from $0.04 \mathrm{~g}$ to $0.12 \mathrm{~g}$ (Table 1). 


\section{Table 1. The weight of SVZ biopsies collected from eight patients}

\begin{tabular}{|l|l|}
\hline Patient & Weight $\mathbf{( g )}$ \\
\hline Patient 1 & 0.08 \\
\hline Patient 2 & 0.13 \\
\hline Patient 3 & 0.12 \\
\hline Patient 4 & 0.10 \\
\hline Patient 5 & 0.04 \\
\hline Patient 6 & 0.05 \\
\hline Patient 7 & 0.10 \\
\hline Patient 8 & 0.10 \\
\hline Patient 9 & 0.12 \\
\hline
\end{tabular}

\section{Primary Human NSC}

Based on the result obtained, we summarized and divided the clinical samples into following three groups having three samples in each group. Group 1: NSC cultured on PDL/Laminin coated flask; Group 2: NSC cultured on CELLstart ${ }^{\mathrm{TM}} \mathrm{CTS}^{\mathrm{TM}}$ coated flask; Group 3: NSC cultured on CELLstart ${ }^{\mathrm{TM}} \mathrm{CTS}^{\mathrm{TM}}$ coated flask with optimized tissue sampling techniques.

\section{Group 1: Patient 1,2 and 3}

In primary human NSC culture of Patient 1, the tissue biopsy obtained was initially digested and divided into two flasks: a PDL/Laminin coated T25 flask and an uncoated T25 flask. Theoretically, neural stem and progenitor cells should attach to the PDL/Laminin coated surface after 24 hours in vitro and grow into monolayer with phase bright sphere cells within 7-14 days of culture. On the other hand, in the uncoated flask, neural stem and progenitor cells should aggregate and grow into freely floating neurosphere of approximately 150 $\mu \mathrm{m}$ in diameter within 7-14 days in vitro. However, here, we did not observe any bright sphere cells attached to the PDL/ Laminin coated layer or any neurosphere aggregated in uncoated flask. On the other hand, high densities of cell debris with spherical shape were found in the culture media after 24 hours in vitro. These results contradicted with our expectation, therefore, the cell suspension from both coated and uncoated flasks were harvested and then further divided into three respective coated and uncoated flasks to double confirm the observation. Yet, after 4 weeks of trial, neural stem and progenitor monolayer cells and neurosphere were still not detected in any of the flasks. Approaching the end stage of experiment, only several neuronal-like cells were found attached in one of the coated flask of Patient 1 (Fig. 1A). Similar results were obtained for the SVZ tissue biopsy obtained from Patient 3, in which, upon approaching the end stage of experiment, only several neuronal-like cells were found attached in one of the coated flask of Patient 3 (Fig. 1B and C). No monolayer cells or neurospheres were observed.

For Patient 2, interestingly, we observed a totally different cell growth pattern compared to Patient 1 and Patient 3. In this patient, monolayer of stem and progenitor cells were found grow on all PDL/Laminin coated flasks (Fig. 2A). The monolayer cells proliferated slowly and became confluent after 4 weeks in vitro. For non-adherent culture, we observed only two neurospheres floated in the media (Fig. 2B). We also observed some cells outgrew from the edge of neurosphere, suggesting the clonal feature of the neurosphere which mimic the stem cell self-renewal characteristics. However, the outgrowth rate was not as rapid as compared to the monolayer cell culture method. After 4 weeks, the cells were harvested and passaged. Unfortunately, the cells were contaminated by bacterial growth after 2 days. Thus, not enough cells were harvested for subsequent characterization assays.

Based on the result obtained for group 1 patients, it was proved that the pilot testing of human NSC culture method done in this study was successful in some extent. We also found that the adherent culture method produced better yield of stem and progenitor cells compared to non-adherent culture method. Therefore, adherent culture system was applied in all subsequent experiments. Furthermore, we modified the adherent coating agent in subsequent experiments to optimize the cell culture method.
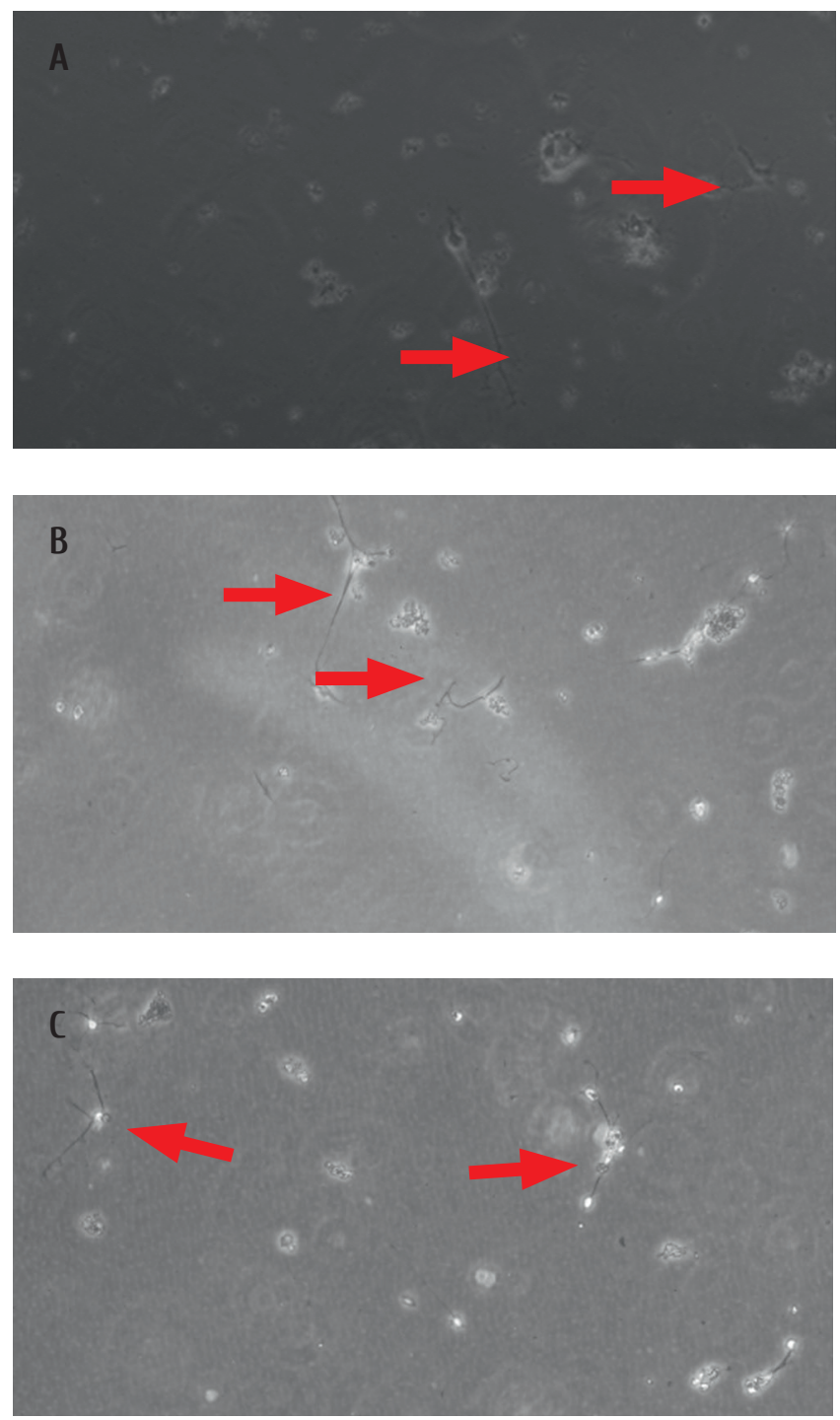

Fig. 1. Neuronal-like cells found in PDL/Laminin coated T-25 flasks of (A) Patient 1 and (B) (C) Patient 3 after 4 weeks in vitro (indicated by red arrows) 

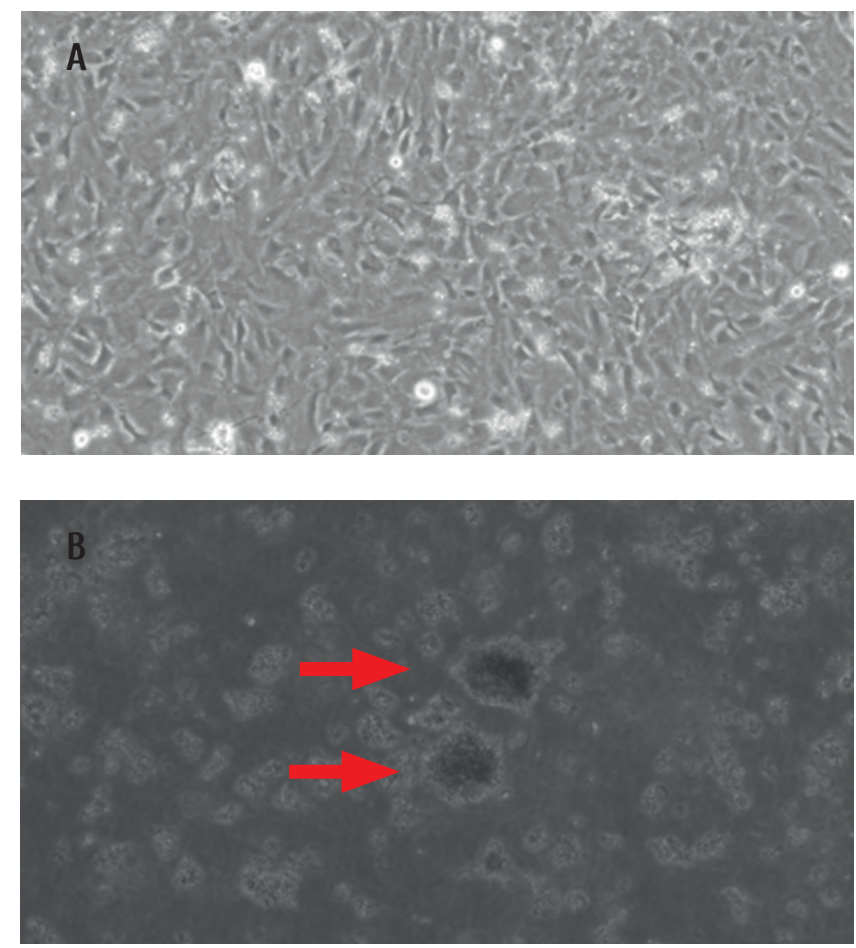

Fig. 2. (A) Monolayer cell and (B) two neurospheres (indicated by red arrows) were observed in the primary NSC culture of Patient 2 after 4 weeks in vitro

Group 2: Patient 4, 5 and 6 (optimized adherent culture method)

For primary NSC culture of Patient 4, CELLstart ${ }^{\mathrm{TM}}$ CTS $^{\mathrm{TM}}$ coated T25 flask was used to culture cell suspension obtained from SVZ brain tissue. CELLstart ${ }^{\mathrm{TM}} \mathrm{CTS}^{\mathrm{TM}}$ was used to replace PDL/laminin as coating agent due to several reasons. First, the incubation time for CELLstart ${ }^{\mathrm{TM}}$ CTS $^{\mathrm{TM}}$ coating method was much shorter than PDL/laminin (1 hour vs 4 hours). This can help to reduce the waiting period after tissue biopsy was excised from patient's brain. Second, CELLstart ${ }^{\mathrm{TM}}$ CTS $^{\mathrm{TM}}$ coating solution was manufactured by GIBCO Invitrogen while PDL/laminin coating solution was self-prepared by researcher in our lab. Thus, the stability and accuracy of CELLstart $^{\text {TM }}$ CTS $^{\text {TM }}$ coating solution was better as compared to PDL/laminin coating solution. The result obtained proved our hypothesis. Neural stem and progenitor cells were found attached to the CELLstart ${ }^{\mathrm{TM}}$ CTS $^{\mathrm{TM}}$ coated surface after 24 hours in vitro and grew into monolayer with phase bright sphere cells after several days (Fig. 3A). After 2 weeks, a confluent monolayer cell with neurospheres attached on the coated layer was observed as shown in Fig. 3B. These cells were harvested and passaged under similar adhesion substrate. We observed similar confluent monolayer cell with neurospheres attached on the coated layer after a week (Fig. $3 \mathrm{C}$ ), proved that these cells possessed active proliferation property. Besides, when the neurospheres was harvested and replated, the neurosphere was found to spread and grew into monolayer (Fig. 3D). These cells were harvested and characterized using immunohistochemistry assay and showed significant expression of Nestin which is a specific marker of NSC (Fig. 4). Besides, the negative staining of GFAP (Fig. 4A) and TUBB3 (Fig. 4B) also further confirmed that these cells were not the glial cell or neuron cells from brain biopsy.
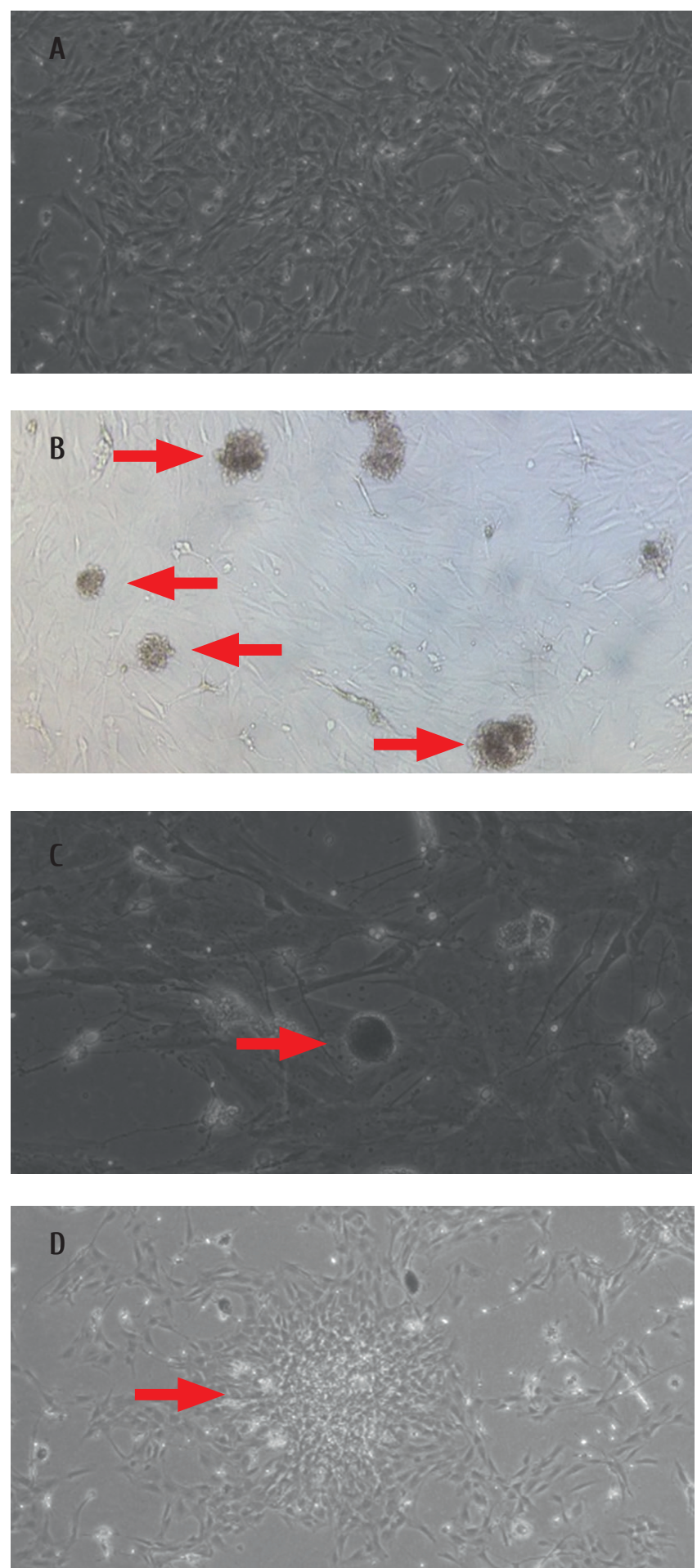

Fig. 3. Primary NSC culture from Patient 4. (A) A monolayer cell was observed after 24 hours of plating; (B) Confluent monolayer cell with neurospheres (indicated by red arrows) attached on the CELLstart ${ }^{\mathrm{TM}}$ CTS $^{\mathrm{TM}}$ coated T-25 flask after 2 weeks; (C) Neural stem and progenitor cells attached along with neurospheres (indicated by red arrow) on coated layer after passage for 1 week; (D) Neurosphere spread and grew into monolayer cells (indicated by red arrow) 
A
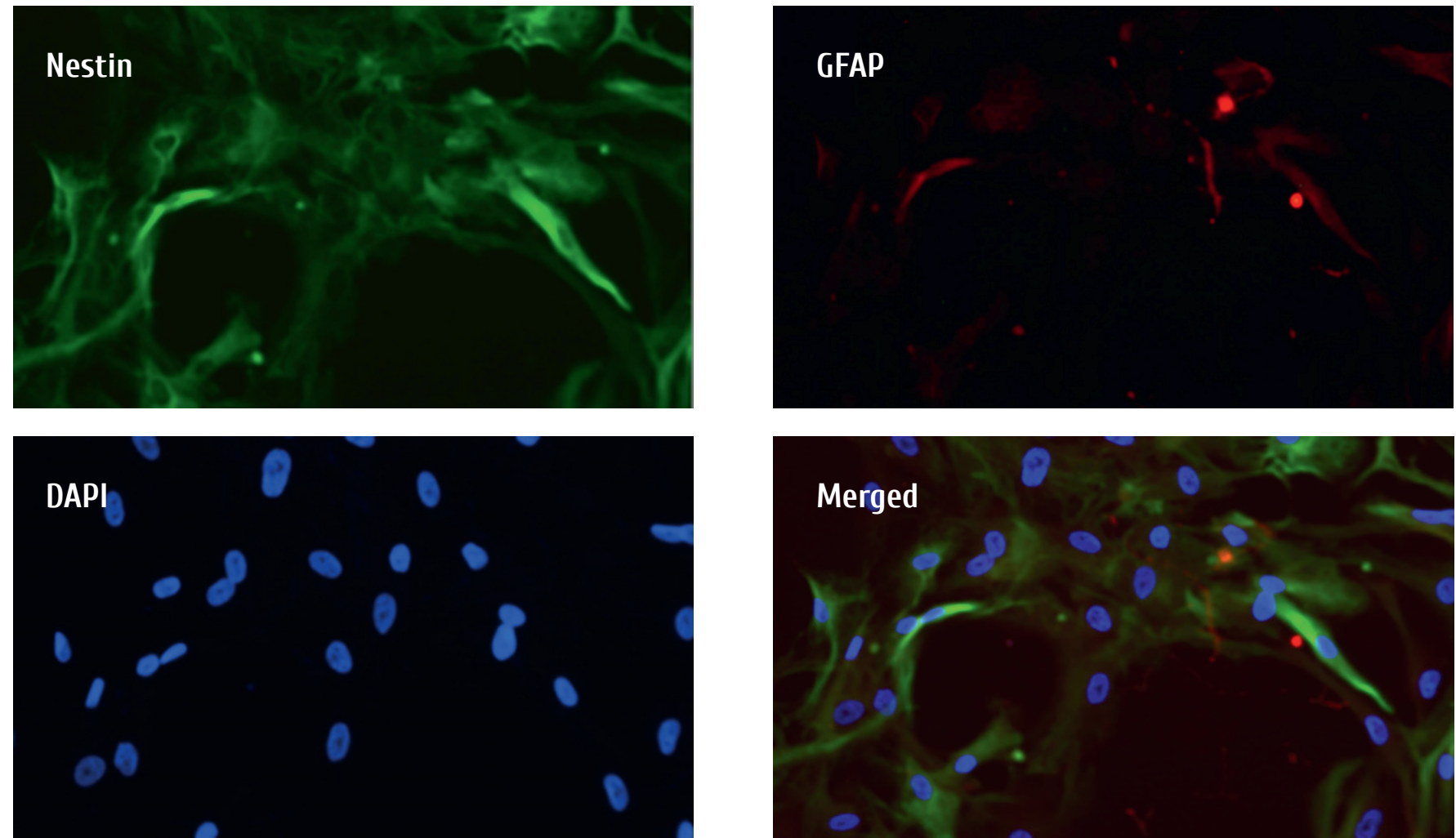

B
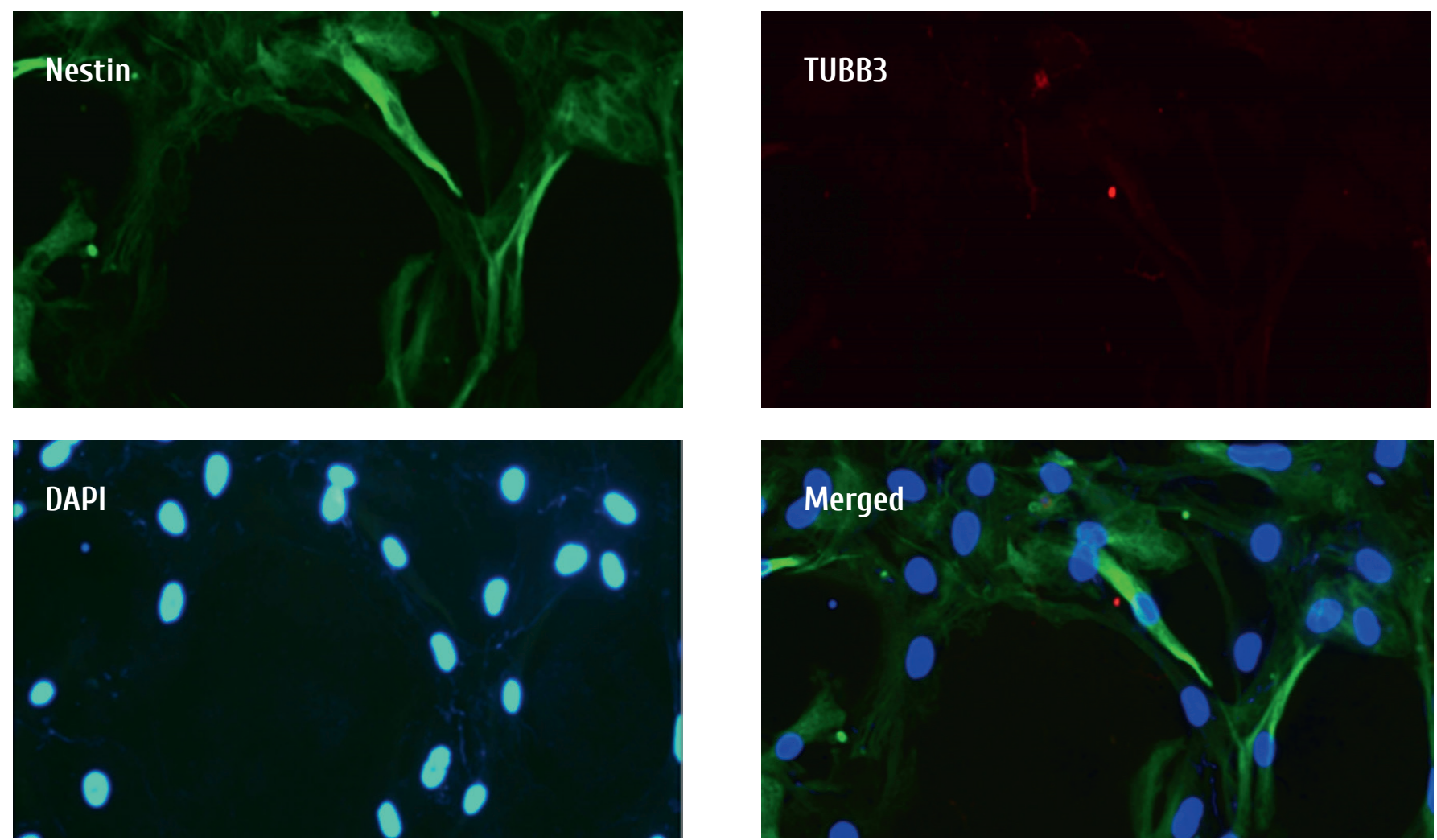

Fig 4. Immunofluorescence images of primary human NSC characterization. Monolayer cell from Patient 4 was positive for NSC marker nestin (green) and negative for (A) glial marker GFAP and (B) neuronal marker TUBB3. Nucleus marker DAPI (Blue) 
In the primary NSC culture of Patient 5, neural stem and progenitor cells were not found in the CELLstart ${ }^{\mathrm{TM}}$ CTS $^{\mathrm{TM}}$ coated T-25 flask. On the other hand, abundant erythrocytes were detected in the culture media (Fig. 5A). After 2 weeks, several neuronal-like cells were attached on the coated layer (Fig. 5B). This was probably due to the error happened during tissue sampling as it was found that most of the tissue excised was blood and connective tissue with minimal visible neuronal tissue (Fig. 5C). The weight of tissue specimen was only $0.04 \mathrm{~g}$, the least among the rest (Table 1 ).
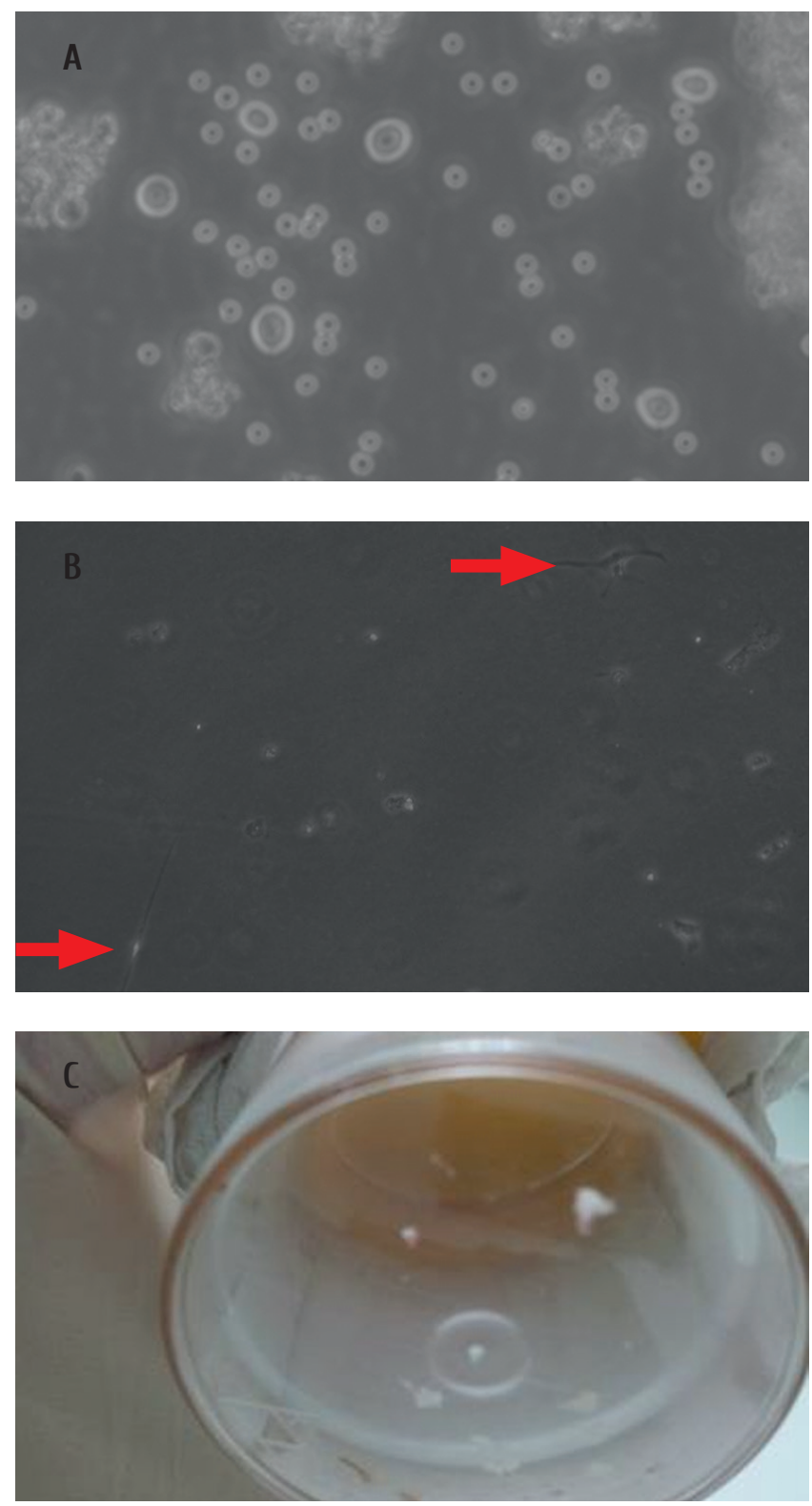

Fig. 5. Primary NSC culture from SVZ biopsy of Patient 5. (A) Large amount of erythrocytes were detected in the culture media; (B) Few neuronal-like cells attached on the coated layer after 2 weeks in culture. (C) The tissue specimen obtained from Patient 5 (weighted $0.04 \mathrm{~g}$ ) was mostly blood and connective tissue with minimal visible neuronal tissue
Unfortunately, similar problem was also observed for the Patient 6, in which the specimen size was only $0.05 \mathrm{~g}$ with barely any neuronal tissue observed (Fig. 6A). Furthermore, it was a 3-hour delay for tissue processing due to unavoidable factors during the surgery. As a consequence, we did not observe monolayer cell on CELLstart ${ }^{\mathrm{TM}}$ CTS $^{\mathrm{TM}}$ coated layer after 24 hours in vitro. Only a few of neuronal-like cells were attached on the coated flask up to 4 weeks post-plating (Fig. 6B).
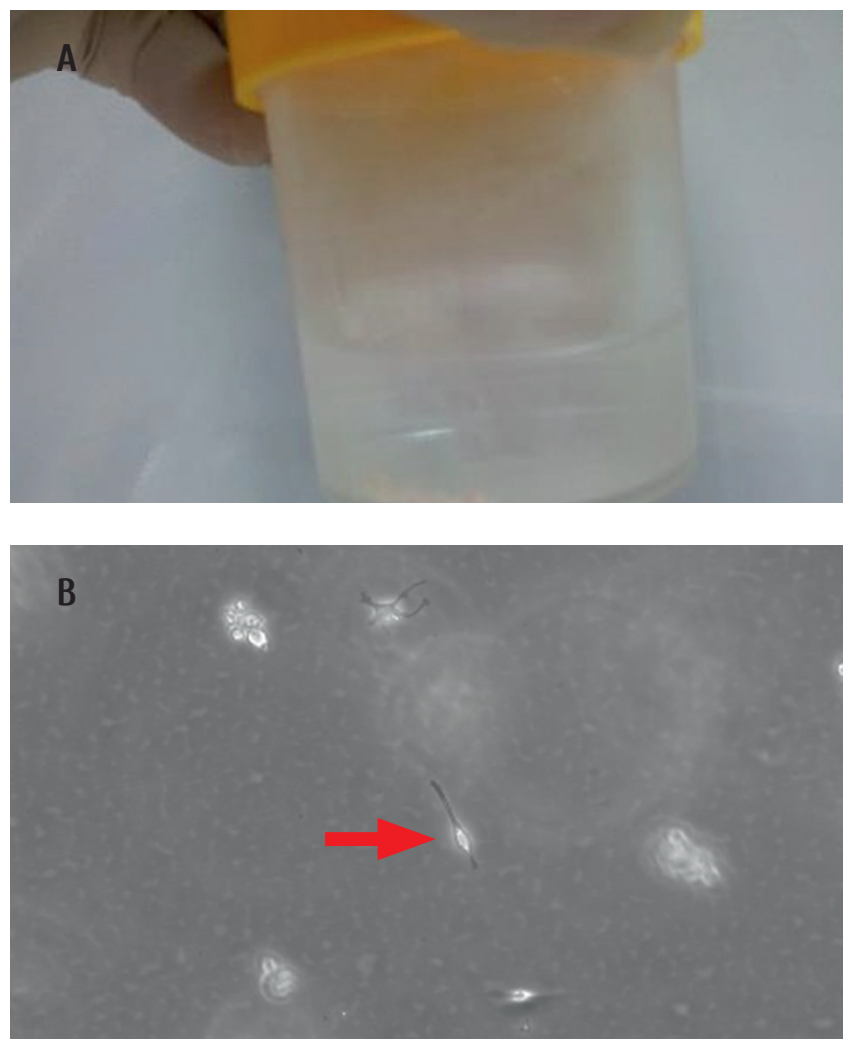

Fig. 6. Primary NSC culture from SVZ biopsy of Patient 6. (A) Tissue specimen obtained from Patient 6 (weighted $0.05 \mathrm{~g})$ with minimal visible neuronal tissue. (B) 0nly a few neuronal-like cell adhered to the coated surface after 2 weeks in culture

After collected data for group 2 patients, it was proved that the technique of tissue sampling and timing to process the tissue specimen without delay are crucial for successful isolation of NSC from human SVZ. We compiled and summarized data obtained and set out a clear sampling standard and applied it in all subsequent experiments.

Group 3: Patient 7, 8 and 9 (using optimized tissue sampling method)

Biopsy from patient 7, 8 and 9 were obtained successfully with high quality, weighted 0.10 to $0.12 \mathrm{~g}$ with no attached blood or connective tissue (Fig. 7A). The tissue specimens were also processed immediately after excision without delay. For all these samples, neuronal cells and neurosphere-like cells were successfully obtained (Fig. 7B-D) and were remained viable for up to 4 weeks. The cells were passaged, cryopreserved and kept for future study. This pilot study had been successfully done to set up a basic guideline for cell culture method and tissue sampling standard for future SVZ-derived NSC research in Hospital USM. 

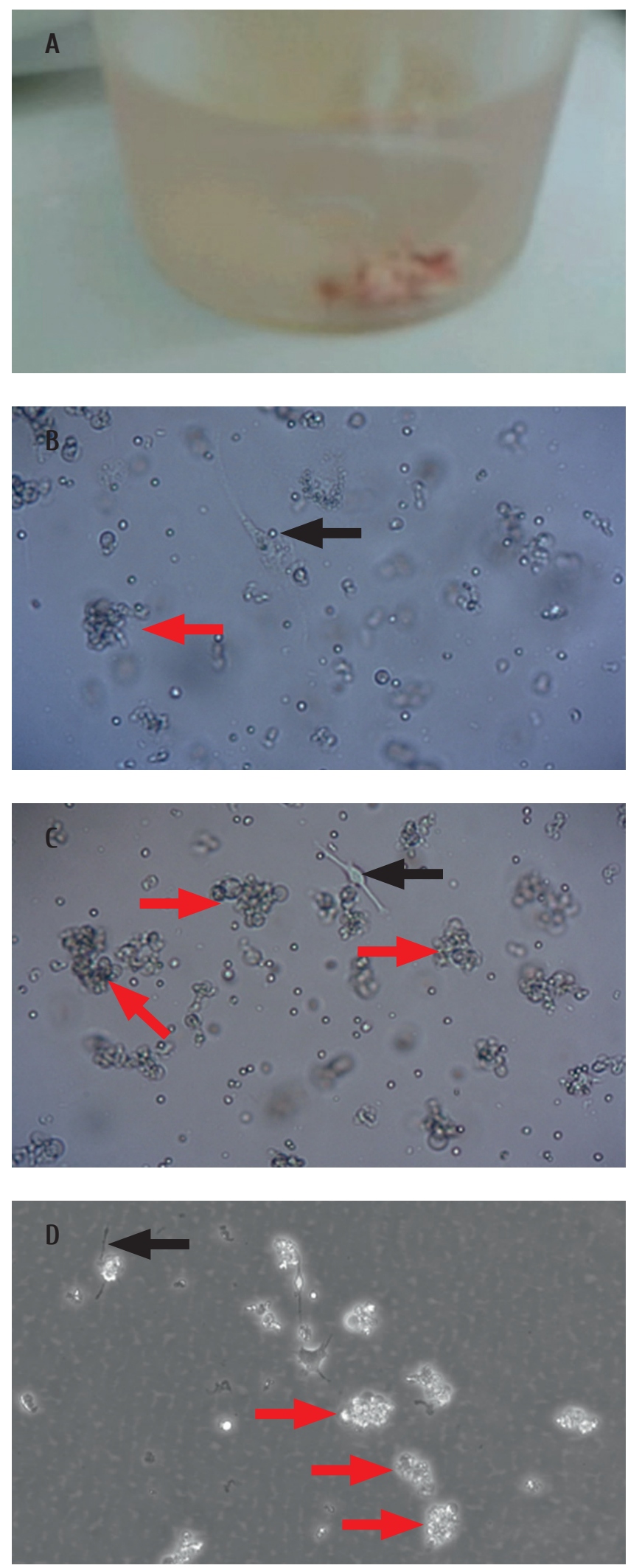

Fig. 7. Primary NSC culture from SVZ biopsy of Patient 7, 8 and 9. (A) Representative picture of good quality tissue specimen (weighted 0.10-0.12 g). Few neuronal(indicated by black arrows) and neurosphere-like (indicated by red arrows) cells were successfully obtained from (B) Patient 7, (C) Patient 8 and (D) Patient 9

\section{Discussion}

SVZ harbors abundant NSCs for neurogenerative therapy. SVZ-derived NSCs are located within the lateral wall of the lateral ventricle and can be isolated endoscopically for autologous transplantation. NSCs are endogenous brain stem cells which function to replenish the brain cells in vivo [19]. Therefore, these cells have great potential to regenerate damaged brain tissue after ischemic stroke. Furthermore, NSCs also have a lower oncogenic potential and immunological rejection as compared to other stem cell types after transplantation [20], therefore, these cells are suitable as therapeutic agent for stroke regenerative treatment.

In this study, SVZ biopsy was obtained with the utilization of stereotactic biopsy needle under neuronavigation system. The advantage of stereotactic approach was the ability to obtain small sized specimen with minimal damage to the neighbouring tissue. This is particularly important to eliminate unnecessary side effects to the donor. Furthermore, proper specimen storage during transportation and minimal delay in specimen processing are crucial to establish primary culture. Any delay or mistakes during the transportation procedure could propagate damage on the excised tissue and affect the efficiency of stem cell isolation. During processing of specimen, enzymatic dissociation using trypsin was performed on finely minced tissues to provide maximum cell recovery and viability. DNase I was also used together with soybean trypsin inhibitor to eliminate membrane-bound DNA and reduce the viscosity.

Under adherent condition, NSCs formed a monolayer cell on adhesion substrate while in the absence of adhesive coating medium, NSCs formed cluster of floating spherical cells known as neurosphere. Nonetheless, overgrown monolayer may also lead to the growth of neurosphere that attached on the adhered cells. Although NSC had limitless potential to proliferate into neurosphere for several passages, the neurospheres obtained from two patients failed to propagate beyond tertiary spheres as compared to previous studies [18, 21]. On the other hand, in this study, monolayer culture managed to expand NSCs beyond passage 3. The ICC results also further validated the stemness of monolayer cell obtained from patients. Thus, this study proposed that neurosphere culture may not be suitable for human SVZ biopsies due to low cell number generated. The neuronal-like cells obtained from other patients suggested that the biopsies were derived from non-neurogenic niches such as blood, connective tissue and perhaps the white matter. Hence, further biopsy required proper target of the NSC niche. It is pivotal to collect the biopsy from the lateral ventricle of the SVZ which may generate sufficient proliferating NSC for several passages.

Here, we tried to analyse the preliminary demographic profile of all the recruited patients with the yield of NSC obtained. Notably, no significant association was able to establish from the patient's reports due the limited sample size and high variability across samples. Therefore, it is imperative to specify recruitment criteria and increase sample size. 


\section{Conclusion}

NSC can be isolated from the SVZ of patients with CVA or traumatic brain injury using stereotactic approach. NSC propagated better in adherent culture coated with CELLstart $^{\mathrm{TM}} \mathrm{CTS}^{\mathrm{TM}}$ as compared to non-adherent culture. Precise SVZ tissue sampling with minimal variability and processing time is required to obtain significant successfully NSC isolation. Further studies with bigger sample sizes are required for a complete demographic profile. Nonetheless, this pilot study successfully set a basic guideline for cell culture method and tissue sampling standard for future SVZ-derived NSC research in Hospital USM. Data obtained from this study could be a stepping stone for the establishment of clinical application of SVZ-derived NSC for clinical stroke therapy in Hospital USM.

\section{Acknowledgements}

This study was funded by USM Research University Individual (RUI) Grant (Grant no: 1001/PPSK/812140). Kang In Nee's studentship is sponsored by MyBrain15, Ministry of Higher Education Malaysia.

No conflicts of interest are reported.

\section{Author contribution statement}

T.S.C. and S.S developed the concepts and designed the experiments. A.R.I.G. performed brain surgery and acquired clinical samples. K.I.N acquired research data. T.S.C. and K.I.N analysed and interpreted the data. T.S.C. and K.I.N wrote the manuscript. T.S.C and K.I.N proofread and gave final approval of the version to be published.

\section{References}

1. Loo KW, Gan SH Burden of stroke in Malaysia. Int J Stroke, 2012; 7(2):165-167.

2. Cheah WK, Hor CP, Zariah AA, Looi I. A review of stroke research in Malaysia from 2000-2014. Med J Malaysia. 2016; 71(Suppl 1):58-69.

3. Jaya F, Win MN, Abdullah MR, Abdullah MR, Abdullah JM. Stroke patterns in Northeast Malaysia: a hospital-based prospective study. Neuroepidemiology, 2002. 21(1): p. 28-35.

4. Mergenthaler P, Lindauer U, Dienel GA, Meisel A. Sugar for the brain: the role of glucose in physiological and pathological brain function. Trends Neurosci., 2013; 36(10): 587597.

5. Lodish H, Berk A, Zipursky SL. Electron Transport and Oxidative Phosphorylation in Molecular Cell Biology. 2000, W.H. Freeman: New York.

6. Dienel GA. Fueling and imaging brain activation. ASN Neuro. 2012. 4(5). doi: 10.1042/AN20120021.

7. Doyle KP, Simon RP, Stenzel-Poore MP. Mechanisms of ischemic brain damage. Neuropharmacology. 2008;55(3):310318 .

8. Brott TG, Haley EC Jr, Levy DE, Barsan W, Broderick J, Sheppard GL, Spilker J, Kongable GL, Massey S, Reed R, et al. Urgent therapy for stroke. Part I. Pilot study of tissue plasminogen activator administered within 90 minutes. Stroke, 1992; 23(5):632-640.

9. Haley EC Jr, Levy DE, Brott TG, Sheppard GL, Wong MC, Kongable GL, Torner JC, Marler JR. Urgent therapy for stroke. Part II. Pilot study of tissue plasminogen activator administered 91-180 minutes from onset. Stroke. 1992; 23(5): 641-645.

10. Grotta J. Should thrombolytic therapy be the first-line treatment for acute ischemic stroke? t-PA--the best current option for most patients. N Engl J Med. 1997; 337(18): 13101313.

11. Grossman AW, Broderick GP. Advances and challenges in treatment and prevention of ischemic stroke. Ann Neurol. 2013; 74(3):363-372.

12. Gritti A, Parati EA, Cova L, Frolichsthal P, Galli R, Wanke E, Faravelli L, Morassutti DJ, Roisen F, Nickel DD, Vescovi AL. Multipotential stem cells from the adult mouse brain proliferate and self-renew in response to basic fibroblast growth factor. J Neurosci. 1996; 16(3):1091-1100.

13. Reynolds BA, Weiss S. Generation of neurons and astrocytes from isolated cells of the adult mammalian central nervous system. Science. 1992; 255(5052):1707-1710.

14. Bond AM, Ming GL, Song H. Adult mammalian neural stem cells and neurogenesis: five decades later. Cell Stem Cell. 2015; 17(4):385-395.

15. Lim DA, Alvarez-Buylla A. The adult ventricular-subventricular zone (V-SVZ) and olfactory bulb (OB) neurogenesis. Cold Spring Harb Perspect Biol. 2016; 8(5). doi: 10.1101/cshperspect.a018820

16. Roy NS, Benraiss A, Wang S, Fraser RA, Goodman R, Couldwell WT, Nedergaard M, Kawaguchi A, Okano H, Goldman SA. Promoter-targeted selection and isolation of neural progenitor cells from the adult human ventricular zone. J Neurosci Res. 2000; 59(3):321-331.

17. Westerlund U, Moe MC, Varghese M, Berg-Johnsen J, Ohlsson M, Langmoen IA, Svensson M. Stem cells from the adult human brain develop into functional neurons in culture. Exp Cell Res. 2003 ;289(2):378-383.

18. Moe MC, Varghese M, Danilov AI, Westerlund U, Ramm-Pettersen J, Brundin L, Svensson M, Berg-Johnsen J, Langmoen IA. Multipotent progenitor cells from the adult human brain: neurophysiological differentiation to mature neurons. Brain. 2005; 128(Pt 9):2189-2199.

19. Aleksandrova MA, Poltavtseva RA, Revishchin AV, Korochkin LI, Sukhikh GT. Development of neural stem/progenitor cells from human brain by transplantation into the brains of adult rats. Neurosci Behav Physiol. 2004; 34(7):659662.

20. Grompe, M. Transition of stem cells to therapeutically functional tissue-specific cells. Ann N Y Acad Sci, 2002;961:305-306.

21. Johansson CB, Svensson M, Wallstedt L, Janson AM, Frisén J. Neural stem cells in the adult human brain. Exp Cell Res, 1999;253(2):733-736. 


\title{
| Выделение нейральных стволовых клеток человека из субвентрикулярной зоны пациентов с инсультом: пилотное исследование в госпитальной клинике Сенс Малайзия
}

\author{
Суат Чен Тан ${ }^{\text {a, }, *}$, Ин Ни Канг ${ }^{\text {a, }}$, Абдул Рахман Изаини Гани ${ }^{\text {b, }}$, Шахарум Шамсуддин ${ }^{\text {a }}$ \\ a Школа наук о здравоохранении, Медицинский комплекс, Госпитальный университет Сенс Малайзия, 16150, Кубан \\ Кериан, Келантан, Малайзия \\ b Школа медицинских наук, Медицинский комплекс, Университет Сенс Малайзия, 16150, Кубан Кериан, Келантан, \\ Малайзия \\ ' Госпиталь Сенс Малайзия, Медицинский комплекс, Университет Сенс Малайзия, 16150, Кубан Кериан, Келантан, \\ Малайзия \\ " Оба автора внесли равный вклад в данную работу
}

\section{Резюме}

Ишемический инсульт вызывается закупоркой церебральных сосудов, что ведет к появлению очага ишемии с необратимым повреждением ткани мозга из-за недостатка кислорода и питательных веществ. Пересадка нейральных стволовых клеток (НСК) развивается в качестве потенциальной регенеративной терапии при инсульте. В данной работе мы описали пилотное клиническое исследование по выделению НСК из субвентрикулярной зоны (СВ3) головного мозга человека. В данной предварительной работе участвовали 9 пациентов, поступивших в госпиталь университета Сенс Малайзия с поражением сосудов головного мозга (ишемическим или геморрагическим инсультом), что потребовало резекции ткани мозга. Во время операции брали биоптаты из СВ3, взвешивали их и регистрировали морфологическую структуру клинических биопсий. Затем биоптаты подвергали перевариванию и культивировали, используя методы нейросфер или монослоя. Из девяти клинических образцов мы успешно получили нейросфероподобные клетки из биоптатов от пяти пациентов, а монослойная культура выросла из СВ3-биоптатов от двух пациентов. Характеризация клеток с посощью иммуноцитохимии выявила наличие нестина (маркера НСК). Это доказывает, что это - нейральные стволовые клет- ки. В остальных образцах выделение НСК из СВЗ не было успешным из-за неудовлетворительного забора тканей CВ3: образцы содержали, главным образом, соединительнотканные элементы или кровь, о чем свидетельствовало накопление плавающих клеток после 24 часов в культуре. В заключение, НСК были успешно получены из СВЗ от некоторых больных с инсультом, однако количество и качество изолированных клеток зависят от исходной ткани. Таким образом, техника интраоперационного забора и размеры биоптатов важны для обеспечения достаточной эффективности выделения НСК. Данное исследование может быть достаточно полезно для дальнейших работ по выделению НСК в нашей клинике.

\section{Ключевые слова}

Первичная изоляция нейральных стволовых клеток, терапия инсульта, госпитальный университет Сенс Малайзия, культура нейросфер и монослоев. 